\title{
Credit Ratings, Cost Of Debt, And Internal Control Disclosures: A Comparison Of SOX 302 And SOX 404
}

\author{
Aaron Crabtree, Ph.D., University of Nebraska-Lincoln, USA
} John J. Maher, Ph.D., Virginia Tech, USA

\begin{abstract}
We compare the effects of SOX 302 and SOX 404 mandated internal control system disclosures on firm credit ratings, changes in credit ratings, and firm cost of debt. We find results consistent with the interpretation that disclosure of firm internal control deficiencies provides incremental information to credit analysts which is negatively associated with a firm's credit rating, and positively associated with cost of debt. Additionally, we find that while disclosures under SOX 302 are negatively related to credit ratings, this effect largely disappears once prior 404 disclosures are considered. Importantly, the impact of 404 internal control disclosures is significant regardless of past 302 disclosures. These results contribute positively to the public policy debate concerning the efficacy of auditor attested internal control evaluations required by SOX 404.
\end{abstract}

Keywords: Internal Control Deficiencies; SOX 302; SOX404

\section{INTRODUCTION}

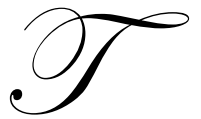

he effectiveness of firm internal control systems is an issue identified by many constituents as crucial to quality external financial reporting. The importance of effective internal control systems achieved a more prominent public profile since the exposure of a series of accounting scandals shortly after the turn of the millennium in which reported earnings were vividly misstated. Congress passed the Sarbanes-Oxley Act of 2002 (SOX) in response to these events in an effort to help restore investor confidence in financial reporting as well as in the U.S. capital markets. Section 302 requires management to provide quarterly reports about the effectiveness of firm internal controls. Section 404 of SOX extends 302 further to require the external auditors to independently attest to the effectiveness of its internal control systems and to publically report any material internal control deficiencies (ICD) discovered. Our research empirically examines the effect of reported material ICD on credit ratings, credit rating changes, and cost of debt. Importantly, we investigate the incremental benefits of the more detailed and auditor attested 404 disclosures on debt markets compared to the less detailed disclosures required under Section $302 .^{1}$

Prior literature in this area has primarily focused on the association between ICD and earnings quality, and the impact of ICD disclosure on cost of equity. We extend this research and examine whether SOX 302 and 404 internal control disclosures provide useful information to knowledgeable capital market participants: creditors and credit rating analysts. At issue is whether the SOX 302 and 404 legislation, which requires ongoing monitoring and reporting costs, also results in significant economic benefits to the credit market, as claimed by law makers (U.S. House of Representatives 2005; U.S. Senate 2004). To the best of our knowledge, our study is the first to extensively examine the impact of SOX 404 ICD disclosures on credit ratings and ex post cost of debt by comparing the information content of the SOX 404 ICD disclosures to credit analysts and creditor versus that under SOX 302 legislation. Lambert et al. (2007) outline a theoretical framework demonstrating that greater information risk is associated with higher cost of capital while Asbaugh-Skaife et al. (2009) show empirically that firms with ICD are

\footnotetext{
${ }^{1}$ See Ashbaugh-Skaife et al. (2008) for a detailed description of the differences in requirements for SOX 302 and SOX 404. 
associated with greater systematic risk. Thus, we predict that SOX 302 and 404 ICD disclosures provide useful information to credit analysts. Moreover, because SOX 404 ICD disclosures are audited by independent accountants and therefore, should be more accurate and rigorous, we posit that the SOX 404 ICD disclosures are more informative to credit analysts than SOX 302 disclosures.

Our findings are consistent with the conjecture that firms reporting ICD have lower credit ratings and higher cost of debt than those not reporting ICD, ceteris paribus. ${ }^{2}$ This result remains robust after controlling for a variety of firm-specific factors. More importantly, our results indicate that the more stringent and detailed reporting requirements of Section 404 provide incremental information relevant to the determination of credit ratings and cost of debt, while the less-detailed disclosures required under SOX 302 do not appear to be a significant, independent factor of either. Overall, these results provide empirical evidence consistent with the interpretation that SOX 404 substantiation related to internal control evaluations provides useful information to credit analysts and creditors; and that these end users of financial information act in a manner consistent with this information being an important factor in determining their ratings.

Our findings augment and complement research conducted in the equity arena with respect to the effects of reported firm internal control deficiencies on firm value (e.g. Asbaugh-Skaife et al. 2008; Asbaugh-Skaife et al. 2009; Doyle et al. 2007). An independent investigation of the effects of internal control deficiencies on credit ratings is important because substantive differences exist between equity holders and bondholders with respect to inherent risk and contingent claims on the firm. The primary external consideration of management is typically the interests of shareholders; the interests of debt-holders are often secondary. Penman (2007) refers to this as the "moral hazard" of debt, which can result in decisions having differential effects on each constituency. Shareholders might prefer to engage in risky projects with high expected returns. Conversely, bondholders are unlikely to be rewarded for this additional risk because their returns are contractually established and would not share in any excess return. Higher risk projects can conceivably add to shareholder wealth through higher expected profits while increasing the risk of default to the bondholders and, therefore, reducing bondholder value. ${ }^{3}$ These inherent differences make the bond market potentially divergent from the equity market and, consequently, a valuable and direct setting in which to empirically examine knowledgeable end-user perceptions related to reported material internal control deficiencies.

We add to the existing literature in at least two ways. First, our results empirically reinforce that SOX 404 ICD disclosures are inversely associated with firm credit ratings and cost of debt as demonstrated in prior studies (Elbannan 2009, Dhaliwal et al. 2009). Elbannan (2009) shows that firms with ICD disclosed under SOX 302 and 404 receive lower credit rating using data from 2003-2005. In a concurrent paper, Dhaliwal et al. (2009) demonstrate further that SOX 404 ICD is associated with higher bond yields. Our paper differs from these two studies in that we present robust evidence that the more-detailed information provided under Section 404 of SOX provides incremental information to credit analysts with respect to the default risk of the firm as compared to the less-detailed and unaudited reporting required by SOX 302.

Our findings should be of interest to both investors and regulators, and contribute to the debate regarding the continuation of the SOX 404 requirement regarding the attestation of internal controls over financial reporting. While we provide evidence consistent with information benefits accruing to credit analysts, our research also indicates that firms maintaining effective internal control systems receive higher credit ratings which is consistent with a lower cost of debt capital. To the extent that reporting requirements of ICD help induce a firm to maintain a better system of internal control, the capital markets benefit by more effective firm reporting systems for financial statements, and the individual firm benefits through a higher credit rating. While our research supports the continued reporting of ICDs under SOX 404, it provides some evidence from the debt markets that might be used to question the efficacy of SOX 302 requirements.

\footnotetext{
${ }^{2}$ We use deficiencies and ICD interchangeably throughout the text.

${ }^{3}$ For a more detailed discussion of differences between the interests of bond holders and shareholders, as well as the agency costs of debt, see Penman 2007, Asbaugh-Skaife et al. 2006, Beatty et al. 2008, Jiang 2008.
} 
The remainder of the paper is structured in the following manner. The next section provides information regarding internal control deficiencies, credit ratings, and a review of relevant literature. Section III describes the methodology while Section IV presents details regarding our sample. Sections V, VI, and VII provide the results. We finish with our conclusions and summary.

\section{MOTIVATION AND RELEVANT RESEARCH}

\section{Internal Control Deficiencies and Regulatory Environment}

Internal controls are defined as "a process, effected by an entity's board of directors, management and other personnel, designed to provide reasonable assurance regarding the achievement of objectives", according to the Committee of Sponsoring Organizations (COSO) ${ }^{4}$. SOX Section 302 took effect on August 29, 2002 and required management to evaluate the effectiveness of internal controls over financial reporting. It also requires the CEO/CFO to certify the internal control effectiveness over financial reporting in quarterly filings (SEC 2002). SOX Section 404 requires management to issue a report on the assessment of the effectiveness of internal controls over financial reporting in annual filings. Importantly, the external auditor must independently issue a report on the effectiveness of internal controls over financial reporting along with an attestation report on management's assessment. Therefore, Section 404 institutes more rigorous disclosure by requiring an auditor to issue an adverse report with respect to the internal controls related to financial statements whenever one or more material ICD is discovered.

In March 2004, the Public Company Accounting Oversight Board (PCAOB) issued Auditing Standard No. 2 (AS2), An Audit of Internal Control over Financial Reporting Performed in Conjunction with an Audit of Financial Statements", which provides detailed guidance and procedures for internal control audits. AS2 became effective for firms with a fiscal year-end on or after November 15, 2004. ${ }^{5}$ The external auditor must issue an adverse opinion on the client's internal control over financial reporting if the auditor establishes the existence of material ICD over financial reporting. Because of the auditor's assertion, in concert with the detailed guidance from AS2, the disclosure of ICD after Section 404 became effective is considered to be more reliable than SOX 302 (AshbaughSkaife et al. 2008).

As prescribed in AS2, possible internal control deficiencies are classified into three categories: control deficiencies, significant deficiencies, and material deficiencies. Material deficiencies are the most severe and represent the focus of our study. Prior to the implementation of SOX Sections 302/404, the only time firms were required to report an internal control deficiency to the SEC was when they changed auditors and also discovered an ICD in the same year. Companies were required to start disclosing internal control deficiencies required by Section 302 of SOX for firms with fiscal year ends after August 29, 2002. Subsequently firms with fiscal year-ends on or after November 15, 2004 (only accelerated filers) started to file audited internal control reports to the SEC required by SOX 404.

Companies assert that costs to comply with Section 404, particularly the auditor attestation requirement, outweigh the benefits received by investors (e.g., American Bankers Association 2005; Microsoft 2005) and call for its repeal or modification. However, regulators insist that Section 404 should ultimately lead to higher quality financial reporting and, consequently, a lower cost of capital (U.S. House of Representatives 2005; U.S. Senate 2004). Credit rating agencies have consistently stated that details related to firm internal control deficiencies provide useful information and can be an important factor in determining credit ratings (Moody's Investor Service 2004, 2007; Fitch 2005).

\footnotetext{
${ }^{4}$ COSO refers to the Committee of Sponsoring Organizations of the Treadway Commission, who undertook an extensive study of internal control to establish a common definition that would serve the needs of companies, independent public accountants, legislators, and regulatory agencies. It provided a framework of criteria that companies could use to evaluate the effectiveness of their internal control systems. COSO published its framework in 1992.

${ }^{5}$ In July 2007, PCAOB issued Auditing Standard No. 5, An Audit of Internal Control Over Financial Reporting That Is Integrated with An Audit of Financial Statements, which supersedes AS2 for firms with a fiscal year-end on or after November $15,2007$.
}

(C) 2012 The Clute Institute http://www.cluteinstitute.com/ 


\section{Research Related to Internal Control Deficiencies}

Extant research predominantly describes negative firm effects as a result of reported ICD, although a few studies in this group report weak associations. Doyle et al. (2007) assert that weak internal controls create opportunities for earnings management and accounting errors which is consistent with Kinney and McDaniel's (1989) contention that weak internal controls can increase the probability of errors in accounting disclosures. Doyle et al. (2007) find that firms reporting material ICD have a weaker association between working capital accruals and cash flows than firms not reporting material ICD and conclude that material ICD are related to lower earnings quality. Similarly, Ashbaugh-Skaife et al. (2007) find a weaker mapping of accruals to cash flows along with more abnormal working capital accruals and abnormal total accruals for firms reporting material ICD. Chan et al. (2007) find mild evidence that firms reporting material ICD have more income increasing and absolute accruals than firms not reporting ICD supporting conclusions reached by previous studies.

Ogneva et al. (2007) explore the relationship between first time ICD reports and firm cost of capital. The authors find higher implied cost of equity capital associated with ICD; however, this relationship disappears after controlling for known firm risk factors. Lambert et al. (2007) show that the quality of financial information and the system that produces it influence the firm's cost of capital in both direct (assessment of the variance and covariance of cash flows by investors) and indirect (decisions made by managers) ways. Ashbaugh-Skaife et al. (2009) examine the relationship between material ICD and firm risk characteristics in light of Lambert et al. (2007) and find that firms reporting material ICD indeed have higher betas, idiosyncratic risk, and cost of equity capital than firms not reporting material ICD.

Hogan and Wilkins (2008) examine the effects of ICD on the costs of conducting an external audit of the firm's financial statements. The authors report that firms reporting material ICD pay higher audit fees than control firms, and interpret their findings to imply that auditors increase their time and efforts when there is an increased level of control risk for the firm as signified by reported ICD. Beneish et al. (2008) examine stock returns around the announcement of ICD under SOX 302 (prior to implementation of 404) and the announcement of ICD under SOX 404. The authors find a negative stock reaction for SOX 302 announcements, but no noticeable reaction to SOX 404 announcements. They attribute the market's non reaction to SOX 404 disclosure to the lower threshold of materiality required by auditors. In comparison, credit rating agencies seem to be more concerned about the ICD disclosed under SOX 404 (Moody's 2004). In both cases, this raises the question of whether both disclosures are now needed.

To the best of our knowledge, no study has examined the differential information contents of SOX 302 and SOX 404 disclosure to credit rating agencies and creditors. Elbannan (2009) examines the disclosure of ICD under 302 and 404 finding firms with ICDs are more likely to have lower ratings and issue bonds of speculative grade. Dhaliwal et al. (2009) finds that firm's credit spread increases after the initial issuance of 404 ICD. The authors also report the effect is more informative for firms that are not monitored by banks or rating agencies. However, neither paper compares the incremental impact of SOX 404 disclosure over SOX 302 disclosure on credit rating and cost of debt.

\section{Credit Ratings and Cost of Debt}

\section{Credit Ratings}

Credit ratings provide a succinct representation of analysts' perception of default risk associated with a firm's outstanding debt. The estimated probability of default is dependent upon a wide range of factors which includes a detailed examination of the firm's financial statements and associated profitability ratios (S\&P Ratings Group 2008). Analysts do not conduct an audit of the financial statements, but rely upon the independent attestation of the firm's external auditor. Any additional information relating to the integrity and veracity of the firm's financial statements would be important in establishing the level of confidence analysts place in the reported numbers. The internal control assessments mandated by SOX can provide additional information related to various aspects of the firm's control effectiveness, and can have direct implications regarding the reported financial statements. Moreover, negative reports regarding a firm's internal control processes can provide a more grievous signal concerning the 
firm's ability to control its operations (Moody's Investors Services 2004). Based upon this environment, we conjecture that SOX-mandated information concerning a firm's internal control effectiveness should be associated with the firm's credit ratings.

Credit ratings are important because they provide an independent appraisal to the market regarding the default risk associated with a firm's debt. Firms raise substantially more "new" funds in the credit market every year than in the equity market to finance new and continuing activities and projects. For example, in 2005 companies raised $\$ 1,187$ billion in the credit market compared to $\$ 141$ billion in the equity market (Investment Dealer's Digest (IDD) 2006). Typically, the process of issuing debt begins with the corporation obtaining a necessary credit rating for the issue from a major rating agency, such as Moody's or Standard \& Poor's, and ends with an investment banker bringing the issue to market. The rating agency's very existence depends upon being independent, along with the associated credibility the public attributes to the ratings it issues. This logical assumption of independence is corroborated by research indicating ratings are motivated more by reputation protection than rating fees obtained from the issuers (Covitz and Harrison 2003). This makes credit ratings an interesting and important area in which to explore the effects of SOX-mandated internal control assessments.

\section{Cost of Debt}

We also examine the effects of internal control disclosures on a firm's cost of debt. While credit ratings are determined by a team of rating analysts, a firm's cost of debt is determined more directly by market investors and provides an alternative way to look at the effects of internal control deficiencies on the overall value of the firm. A significant body of research exists which explores various accounting-related questions by investigating effects on a firm's cost of debt capital. For example, Anderson et al. (2004) examine board of director characteristics and accounting report integrity and find that more independent board of directors and larger board size result in a lower cost of debt. They also find that fully independent audit committees that meet frequently appear to increase the quality of accounting reports which correspondingly helps to reduce the cost of debt capital. Mansi et al. (2004) find that firms engaging a Big 4 auditor achieve lower debt costs through increasing the perceived reliability of their financial statements, as well as obtaining the additional insurance protection Big 4 auditors are conjectured to provide by ostensibly protecting investors from future losses from audit failure. In summary, there is a considerable literature that illustrates how examination of the cost of debt can provide beneficial insights with respect to questions germane to the accounting profession. We implement the approach and basic model described in Francis et al. (2005) and utilize a firm's relative cost of debt to examine the effects of SOX 302 and SOX 404 ICD disclosures on a firm's cost of debt capital.

\section{Primary Hypothesis}

Asbaugh-Skaife et al. (2008) find that ICD disclosures under the SOX 302 period have considerable classification errors. Because the SOX 302 and SEC interpretation do not provide any guidance or procedures for evaluating internal controls, it is not surprising that the ICD disclosure in the SOX 302 period is not entirely reliable. In contrast, SOX 404 mandates that independent auditors express an opinion over management's evaluation of the effectiveness of internal controls over financial reporting. Moreover, the PCAOB issued AS2 which outlines detailed procedures for the audits of internal controls, and companies continued to also disclose ICD information under SOX 302 in the SOX 404 period. Beneish et al. (2008) find a negative stock market reaction to the announcement of ICD under 302 but not under 404 in contrast to the above information. We predict, with credit agencies placing value on the audit procedure, that the ICD disclosures required by SOX 404 provide richer and more accurate internal control information to the credit rating agencies relative to those required by SOX 302 . Stated formally, our primary hypothesis is:

H1: Internal control deficiency disclosures based upon SOX Section 404 are more closely associated with the determination of firm credit ratings and cost of debt than disclosures provided by SOX Section 302 .

The results of our investigation into this hypothesis should provide beneficial insight regarding the importance of SOX 404 disclosures for credit rating analysts. 


\section{METHODOLOGY}

We examine our hypothesis in three settings. First, we examine the relationship between ICDs and credit ratings. Next, we study ratings changes around the announcement of ICDS. And lastly, we consider the effect of ICDs on firm cost of debt.

\section{Ordered Logit Model for Cross-Sectional Analysis}

Based on prior research completed in the credit rating area (e.g. Kaplan and Urwitz 1979; Asbaugh-Skaife et al. 2006; Jiang 2008; Lee 2008), we adopt the following ordered logit model for our cross-sectional analysis of the effect of internal control effectiveness over financial reporting on credit ratings. Our model controls for company and issue specific factors that are likely to affect bond ratings.

RATING $=\quad$ Intercepts $+\beta_{1}$ (Internal Control $)+\beta_{2}$ SIZE $+\beta_{3}$ ROA $+\beta_{4}$ CFO $+\beta_{5}$ LOSS $+\beta_{6}$ LEV + $\beta_{7}$ TIMES $+\beta_{8}$ SUBORD $+\beta_{9}$ CAPINT $+\beta_{10}$ BM $+\beta_{11} \operatorname{Ln}($ STD_RET $)+\beta_{12}$ MERGER + $\beta_{13}$ RESTATE $+\beta_{14}$ RATING $_{\mathrm{t}-1}+$ Industry Fixed Effects + Year Fixed Effects $+e$

RATING is the numerical credit rating transformed from the Standard and Poor's raw letter ratings as shown in Appendix A following the methodology utilized in prior literature (Ashbaugh-Skaife et al. 2006). RATING takes the values from 7 to 1 with a higher number indicating better credit ratings.

Our experimental variable is Internal Control. We use multiple measures to explore the relation between internal control effectiveness and credit ratings. The first measure, DEF404, takes the value of 1 if a company receives an adverse opinion on its internal control effectiveness with respect to financial reporting from its auditor as required by SOX 404, and 0 otherwise. The second measure, DEF302, takes the value of 1 if a company discloses an ICD in the first three quarters of the year under SOX 302. In order to examine the relative importance of SOX 404 information versus SOX 302 information we develop a series of four indicator variables that we utilize to provide further insight into this issue. The first of these variables, DEF404+302, takes the value of 1 if a company receives an adverse opinion for an ICD from its auditor and it also disclosed an ICD under 302 earlier in the year, and 0 otherwise. The variable, DEF404-302, takes the value 1 if a company receives an adverse opinion for an ICD from its auditor while having no 302 disclosure during the year. These variables allow us to examine the relative importance of a 404 disclosure versus 302 disclosures. Next we create DEF302+404 which takes the value 1 when a firm reports an ICD under 302 during the year and also had an adverse opinion for an ICD under 404 in the prior year. Our last measure is DEF302-404. It takes the value 1 when a firm reports an ICD under 302 during the year, but had no adverse 404 opinion in the prior year. These last two variables represent the importance of 302 disclosures conditioned on information already announced based upon 404.

We include various firm-specific variables in model (1) to control for potential determinants of credit ratings based on prior literature (e.g. Kaplan and Urwitz 1979; Ziebart and Reiter 1992; Asbaugh-Skaife et al. 2006; Jiang 2008; Lee 2008). Large firms (SIZE) have lower financial risk and less likely to incur credit default and, thus, is expected to be associated with higher credit ratings. Firms with greater profitability (ROA) and higher level of cash flows (CFO) have stronger financial strength, and thus, are expected to have higher ratings. In contrast, firms reporting losses (LOSS) and firms with higher leverage (LEV) are more likely to incur financial default and, thus, receive lower ratings. Moreover, firms with higher times-to-interest earned ratio (TIMES) and firms with greater capital intensity (CAPINT) are found to be associated with sounder financial positions and, therefore, are rated higher. A firm is considered to receive lower credit rating if the firm has subordinated debt (SUBORD) because subordinated debts are financially riskier than senior debts. Firms with higher book-to-market ratio have poor market performance thus are expected to receive lower credit ratings. Jiang (2008) shows firms with greater equity volatility receive lower credit ratings and, thus, we include $\operatorname{Ln}($ STDRET) in our model. To control for carryover effects from business transactions and past accounting problems, we include MERGER to indicate if a firms has been involved in a merger or acquisition and RESTATE to indicate if a firm has restated its earnings. Following Jiang (2008), we add lagged credit ratings RATING t $-1_{1}$ to control for omitted correlated variables and autocorrelation of the error terms. Finally, we include industry fixed effects and year fixed effects following Jiang (2008) and Lee (2008). 


\section{Impact of Internal Control Effectiveness on Changes in Credit Ratings}

We next investigate whether announced internal control deficiencies have any impact on changes in a firm's credit rating. We employ the same basic approach utilized in Equation (1) and develop the following ordered logit changes model to test our predictions.

$\begin{array}{ll}\Delta \mathrm{RATING}_{-} 1 \mathrm{M}= & \text { Intercepts }+\beta_{1} \text { Internal Control }+\beta_{2} \Delta \mathrm{SIZE}+\beta_{3} \Delta \mathrm{ROA}+\beta_{4} \Delta \mathrm{CFO}+\beta_{5} \Delta \mathrm{LOSS}+\beta_{6} \Delta \mathrm{LEV}+ \\ & \beta_{7} \Delta \mathrm{TIMES}+\beta_{8} \Delta \text { SUBORD }+\beta_{9} \Delta \mathrm{CAPINT}+\beta_{10} \Delta \mathrm{BM}+\beta_{11} \Delta \mathrm{Ln}(\mathrm{STD} \text { RET })+ \\ & \beta_{12} \Delta \text { MERGER }+\beta_{13} \Delta \text { RESTATE }+e\end{array}$

$\triangle$ RATING_1M is the change of Standard and Poor's senior debt ratings in the month after the internal control report is filed with the SEC relative the debt rating in the month before the filing month.

$\triangle$ RATING_3M is the change of credit rating for the three-month window of $[\mathrm{m}-1, \mathrm{~m}+1]$ where ' $\mathrm{m}-1$ ' ' is one month before internal control report filing month and " $\mathrm{m}+1$ " means one month after the internal control report filing month.

Internal Control is the same as defined in Equation (1). Utilizing " $\Delta$ " before other variables represents the change of the variable in current fiscal year relative to the prior fiscal year. These variables are also the same as defined in Equation (1). We include industry and year fixed effects to control for potential industry effects and the impact due to economic cycle on credit rating. The predictions on the signs of the control variables are the same as those in the levels regressions in Equation (1).

\section{Impact of Internal Control Effectiveness on Ex Post Cost of Debt}

Next, we adopt the following model to test the impact of ICD disclosures on ex post cost of capital.

$\mathrm{COD}=\quad$ Intercepts $+\lambda_{1}$ (Internal Control $)+\lambda_{2} \mathrm{RATING}+\lambda_{3} \mathrm{SIZE}+\lambda_{4} \mathrm{ROA}+\lambda_{5} \mathrm{CFO}+\lambda_{6} \mathrm{LOSS}+\lambda_{7} \mathrm{LEV}+$ $\lambda_{8}$ TIMES $+\lambda_{9}$ SUBORD $+\lambda_{10}$ CAPINT $+\lambda_{11}$ BM $+\lambda_{12}$ Ln(STD_RET $)+\lambda_{13}$ MERGER + $\lambda_{14}$ RESTATE + Industry Fixed Effects + Year Fixed Effects $+e$

Following Francis et al. (2005), COD is the ex post cost of debt, defined as total interest expense divided by the sum of average short-term and long-term debts. Because credit rating is closely related to cost of debt, we control for the credit rating for the current period (RATING). We predict that firms with better corporate credit rating incur lower cost of debt. Similar to the control variables in Equation (1), we further control for various firmspecific characteristics. We expect large firms (SIZE), more profitable firms (ROA), firms with greater level of operating cash flows (CFO), firms with higher times-to-interest earned ratio (TIMES) and firms with greater capital intensity (CAPINT) report lower cost of debt. In contrast, we predict that loss firms (LOSS), firms with subordinated debt (SUBORD), high leveraged firms (LEV), firms with greater equity volatility (STD_RET), firms having merger and acquisitions (MERGER) and firms restating prior financial statements (RESTATE) incur higher cost of debt. Finally, we include industry fixed effects and year fixed effects.

\section{SAMPLE}

Variables related to the effectiveness of internal control over financial reporting are obtained from the AuditAnalytics SOX 404 Internal Controls file for the period of 2004 to 2007. The file compiles auditors' opinions on the effectiveness of internal control over financial reporting. Credit ratings are downloaded from the Compustat Ratings file which reports the monthly domestic long-term issuer credit ratings of S\&P 1500 companies. Firmspecific financial information is also obtained from Compustat. After merging data from the three databases and deleting missing values, we have 4,825 firm-year (5,795 firm-quarter) observations for the SOX 404 (SOX 302) Disclosure sample, representing 1,377 (770) unique firms for further analyses.

Table 1 Panel A shows the descriptive statistics for the SOX 404 sample, while Panel B provides the statistics for the SOX 302 sample. To mitigate the impact of outliers, all continuous variables except credit rating scores are winsorized at the top and bottom $1 \%$ of their distributions. In the analysis of cost of debt, we delete the 
top and bottom $1 \%$ of the distribution of cost of debt because of the noisiness of the measure (Francis et al. 2005). The mean (median) of the credit rating scores is 3.473 which is equivalent to a letter rating of "BBB-" to "BB+". Among these observations, 312 observations report material deficiencies of internal control over financial reporting.

Table 1 Descriptive Statistics

Panel A: SOX 404 Disclosure Sample (Annual Sample)

\begin{tabular}{|c|c|c|c|c|c|c|}
\hline Variables & $\mathbf{N}$ & Mean & Std Dev & 25th Pctl & 50th Pctl & 75th Pctl \\
\hline RATING & 4,825 & 3.473 & 1.159 & 3 & 3 & 4 \\
\hline RATEINGt-1 & 4,825 & 3.508 & 1.143 & 3 & 3 & 4 \\
\hline DEF404 & 4,825 & 0.065 & 0.246 & 0 & 0 & 0 \\
\hline SIZE & 4,825 & 8.350 & 1.400 & 7.340 & 8.198 & 9.306 \\
\hline ROA & 4,825 & 0.097 & 0.063 & 0.057 & 0.088 & 0.130 \\
\hline $\mathrm{CFO}$ & 4,825 & 0.097 & 0.066 & 0.055 & 0.09 & 0.134 \\
\hline LOSS & 4,825 & 0.169 & 0.375 & 0 & 0 & 0 \\
\hline LEV & 4,825 & 0.296 & 0.192 & 0.165 & 0.265 & 0.384 \\
\hline $\mathrm{RD}$ & 4,825 & 0.014 & 0.029 & 0 & 0 & 0.013 \\
\hline TIMES & 4,825 & 2.140 & 0.896 & 1.530 & 2.006 & 2.642 \\
\hline SUBORD & 4,825 & 0.185 & 0.388 & 0 & 0 & 0 \\
\hline CAPINT & 4,825 & 0.636 & 0.386 & 0.306 & 0.603 & 0.928 \\
\hline $\mathrm{BM}$ & 4,825 & 0.450 & 0.672 & 0.261 & 0.444 & 0.658 \\
\hline STD_RET & 4,825 & 2.336 & 1.478 & 1.421 & 1.995 & 2.838 \\
\hline MERGER & 4,825 & 0.524 & 0.499 & 0 & 1 & 1 \\
\hline RESTATE & 4,825 & 0.092 & 0.289 & 0 & 0 & 0 \\
\hline COD & 3,575 & 0.070 & 0.021 & 0.057 & 0.068 & 0.081 \\
\hline Variable & $\mathbf{N}$ & Mean & Std Dev & 25th Pctl & 50th Pctl & 75th Pctl \\
\hline$\Delta$ RATING $[\mathrm{m}-1, \mathrm{~m}+1]$ & 4,570 & -0.007 & 0.163 & 0 & 0 & 0 \\
\hline$\triangle$ SIZE & 4,570 & 0.089 & 0.210 & -0.009 & 0.06 & 0.147 \\
\hline$\triangle \mathrm{ROA}$ & 4,570 & 0.004 & 0.047 & -0.011 & 0.003 & 0.017 \\
\hline$\triangle \mathrm{CFO}$ & 4,570 & 0.000 & 0.049 & -0.023 & 0.001 & 0.023 \\
\hline$\Delta \mathrm{LOSS}$ & 4,570 & 0.014 & 0.382 & 0 & 0 & 0 \\
\hline$\triangle \mathrm{LEV}$ & 4,570 & 0.001 & 0.128 & -0.037 & -0.006 & 0.030 \\
\hline$\Delta \mathrm{RD}$ & 4,570 & 0.000 & 0.006 & 0 & 0 & 0 \\
\hline$\Delta$ TIMES & 4,570 & 0.006 & 0.439 & -0.137 & 0.039 & 0.194 \\
\hline$\triangle$ SUBORD & 4,570 & -0.011 & 0.202 & 0 & 0 & 0 \\
\hline$\triangle$ CAPINT & 4,570 & 0.001 & 0.084 & -0.028 & 0.004 & 0.033 \\
\hline$\Delta \mathrm{BM}$ & 4,570 & 0.046 & 0.318 & -0.062 & 0.014 & 0.113 \\
\hline$\Delta \mathrm{STD} \_\mathrm{RET}$ & 4,570 & 0.148 & 0.380 & -0.115 & 0.073 & 0.344 \\
\hline$\triangle \mathrm{MERG} G \mathrm{R}$ & 4,570 & 0.010 & 0.473 & 0 & 0 & 0 \\
\hline$\triangle$ RESTATE & 4,570 & -0.012 & 0.382 & 0 & 0 & 0 \\
\hline
\end{tabular}

Variable Definitions

$\begin{array}{ll}\text { RATING } & \text { Standard and Poor's senior debt ratings made one month after SOX } 404 \text { internal control filing } \\ & \text { month to the SEC. } \\ & =1 \text { if a company's internal control over financial reporting has material deficiency, as identified } \\ \text { bEF404 } & =\text { natural logarithm of total assets at the end of fiscal year. } \\ & =\text { return on assets, measured by earnings before interests and tax divided by total assets at the end } \\ \text { SIZE } & =\text { of fiscal year. } \\ \text { ROA } & =1 \text { if net income is negative, } 0 \text { otherwise. } \\ \text { CFO } & =\text { total long-term debt divided by total assets, both at the end of fiscal year. } \\ \text { LOSS } & =\text { research \& development divided by total assets, both at the end of fiscal year. } \\ \text { LEV } & =\text { natural logarithm of }(1+\text { times-to-interest earned ratio). Times-to-interest earned ratio is } \\ \text { RD } & \text { measured by operating income before depreciation divided by interest expense. } \\ \text { TIMES } & \end{array}$


Table 1: (cont'd)

$\underline{\text { Panel A (cont'd) }}$

SUBORD

CAPINT

$\mathrm{BM}$

STD_RET

MERGER

RESTATE

COD
$=1$ if a company has a balance of subordinated debt, 0 otherwise.

$=$ gross PPE divided by total assets

$=$ total equity divided by market value of equity, both measured at the year end.

$=$ standard deviation of daily stock returns for the year.

$=1$ if a company has merger and acquisition activities, 0 otherwise

$=1$ if a company makes an announcement of restatement of financial statements in the year,

0 otherwise

$=$ total annual interest expense divided by the sum of average short-term and long-term debts.

$\triangle \mathrm{RATING}[\mathrm{m}-1, \mathrm{~m}+1]$

$=$ change of credit ratings from one month prior to SOX 404 filing month [m-1] to one month after

SOX 404 filing month [m+1].

" $\Delta$ " represents the change of the variable from previous year to current year.

Panel B: SOX 302 Disclosure Sample (Quarterly Sample: Quarters 1-3)

\begin{tabular}{|c|c|c|c|c|c|c|}
\hline Variables & $\mathbf{N}$ & Mean & Std Dev & 25th Pctl & 50th Pctl & 75th Pctl \\
\hline RATINGQ & 5,795 & 3.515 & 1.129 & 3 & 4 & 4 \\
\hline RATINGQ_1 & 5,795 & 3.520 & 1.132 & 3 & 4 & 4 \\
\hline DEF302 & 5,795 & 0.062 & 0.240 & 0 & 0 & 0 \\
\hline SIZEQ & 5,795 & 8.300 & 1.351 & 7.351 & 8.217 & 9.261 \\
\hline ROAQ & 5,795 & 0.013 & 0.018 & 0.005 & 0.013 & 0.022 \\
\hline CFOQ & 5,795 & 0.042 & 0.048 & 0.014 & 0.035 & 0.065 \\
\hline LOSSQ & 5,795 & 0.135 & 0.342 & 0 & 0 & 0 \\
\hline LEVQ & 5,795 & 0.303 & 0.188 & 0.174 & 0.274 & 0.388 \\
\hline RDQ & 5,795 & 0.002 & 0.006 & 0 & 0 & 0 \\
\hline TIMESQ & 5,795 & 2.135 & 0.922 & 1.546 & 2.039 & 2.647 \\
\hline SUBORDQ & 5,795 & 0.164 & 0.370 & 0 & 0 & 0 \\
\hline CAPINTQ & 5,795 & 0.687 & 0.375 & 0.367 & 0.673 & 0.981 \\
\hline BMQ & 5,795 & 0.427 & 0.392 & 0.247 & 0.411 & 0.597 \\
\hline STD_RETQ & 5,795 & 1.839 & 1.097 & 1.157 & 1.687 & 2.360 \\
\hline MERGERQ & 5,795 & 0.382 & 0.486 & 0 & 0 & 1 \\
\hline RESTATEQ & 5,795 & 0.027 & 0.162 & 0 & 0 & 0 \\
\hline CODQ & 5,539 & 0.017 & 0.006 & 0.014 & 0.017 & 0.020 \\
\hline Variable & $\mathbf{N}$ & Mean & Std Dev & 25th Pctl & 50th Pctl & 75th Pctl \\
\hline$\Delta$ RATINGQ $[\mathrm{m}-1, \mathrm{~m}+1]$ & 5,322 & -0.001 & 0.090 & 0 & 0 & 0 \\
\hline$\triangle$ SIZEQ & 5,322 & 0.108 & 0.228 & 0.004 & 0.068 & 0.153 \\
\hline$\triangle \mathrm{ROAQ}$ & 5,322 & 0.000 & 0.017 & -0.004 & 0 & 0.005 \\
\hline$\triangle \mathrm{CFOQ}$ & 5,322 & -0.000 & 0.036 & -0.014 & 0 & 0.014 \\
\hline$\triangle \mathrm{LOSSQ}$ & 5,322 & 0.001 & 0.356 & 0 & 0 & 0 \\
\hline$\triangle \mathrm{LEVQ}$ & 5,322 & -0.001 & 0.088 & -0.038 & -0.009 & 0.023 \\
\hline$\triangle \mathrm{RDQ}$ & 5,322 & 0.000 & 0.002 & 0 & 0 & 0 \\
\hline$\triangle$ TIMESQ & 5,322 & -0.009 & 0.536 & -0.174 & 0.028 & 0.209 \\
\hline$\triangle \mathrm{SUBORDQ}$ & 5,322 & -0.005 & 0.178 & 0 & 0 & 0 \\
\hline$\triangle$ CAPINTQ & 5,322 & -0.006 & 0.096 & -0.033 & 0.002 & 0.033 \\
\hline$\triangle \mathrm{BMQ}$ & 5,322 & 0.019 & 0.259 & -0.062 & 0.008 & 0.094 \\
\hline$\triangle \mathrm{STD}$ _RETQ & 5,322 & 0.006 & 0.489 & 0 & 0 & 0 \\
\hline$\triangle$ MERGERQ & 5,322 & 0.272 & 0.909 & -0.190 & 0.090 & 0.618 \\
\hline$\triangle$ RESTATEQ & 5,322 & 0.000 & 0.218 & 0 & 0 & 0 \\
\hline
\end{tabular}

The descriptive statistics of the control variables are relatively consistent with prior research concerning the debt market (e.g. Jiang 2008; Ashbaugh-Skaife, et al. 2006). The mean and median of the natural logarithm of total assets (SIZE) are 8.350 and 8.198. The sample is generally profitable (ROA is about 9.7\%) and operating cash flows (CFO) account for about $9.7 \%$ of the total assets while $16.9 \%$ of firm-year observations report negative net income (LOSS). Long-term debt accounts for about $29.6 \%$ of total assets. The natural log of times-to-interest earned ratio (TIMES) is 2.140 and is similar to that reported in Jiang (2008). A minority of the observations (18.5\%) issue 
subordinated debt (SUBORD) and gross PPE (CAPINT) accounts for $63.6 \%$ of total assets. The average book-tomarket ratio (BM) is 0.450 The mean of the standard deviation of daily returns (STD_RET) is about 0.019. More than half of the sample (52.4\%) involves merger and acquisition activities (MERGER) and slightly greater than 9\% of them have restatement announcements. Lastly, the cost of debt (COD) averaged 7\% for the reduced sample $(n=3,575)$. Overall, our sample appears to be representative of the type of company that issues public debt and should provide a reasonable setting in which to apply our analyses.

We also report the sample to examine the change of annual credit ratings. The sample size is slightly smaller as we delete firm-year observations with only one-year data. For brevity, we do not discuss these statistics and we believe these statistics are reasonable and consistent with other papers (Jiang 2008).

Panel B reports the descriptive statistics of the sample used for the SOX 302 analysis. There are 5,795 firm-quarter observations representing 777 unique firms during quarters 1 to 3 . We do not use quarter 4 for this analysis in that the fourth quarter SOX 302 report coincides with SOX 404 reports. The descriptive statistics of credit ratings (RATINGQ) are comparable to those reported in Panel A. The mean of SOX 302 ICD (DEF302) is 0.062 indicating there are 357 firm-quarter observations reporting SOX 302 ICD during the period. The statistics for SIZEQ, LOSSQ, LEVQ, TIMESQ, SUBORDQ, CAPINTQ, BMQ and STD_RETQ are comparable to those of the annual variables reported in Panel A. Those for ROAQ, CFOQ, RDQ, MERGERQ, RESTATEQ and CODQ are lower than those annual counterparts but remain intuitively reasonable.

\section{RESULTS: CROSS-SECTIONAL ANALYSIS}

\section{Univariate Analysis}

The correlation matrix for the level of credit ratings variables is shown in Table 2 Panel A, while Panel B provides the correlations for the change in credit ratings variables. The largest bi-variate correlations with firm credit ratings are found for SIZE (0.574), TIMES (0.566), and Leverage (-0.483). All other variables display smaller correlations, but are also consistent with expectations for univariate analyses. Overall, there is nothing displayed in the correlations that would indicate a problem in running our multivariate analyses.

\section{Multivariate Analysis}

Table 3 provides the results from our ordered logit models and indicates that all models are highly significant $(\mathrm{p}<0.001)$. The dependent variable is the transformed S\&P credit rating. In the first model, the independent variable of interest is DEF404 which is 1 for firms reporting material SOX 404 internal control deficiencies and 0 otherwise. The generalized R-square is 0.755 and is consistent with other studies (e.g. Jiang 2008; Lee 2008; Ashbaugh-Skaife et al. 2006). The coefficient on DEF404 is significant ( $p=0.006)$ consistent with our supposition that firms with material deficiencies have significantly lower credit ratings compared to firms without material deficiencies, ceteris paribus. These results provide strong support for the prediction that internal control deficiencies are associated with lower credit ratings. The coefficients on the control variables are generally consistent with predictions and therefore not discussed for brevity. Overall, the results are consistent with findings from prior studies (e.g. Lee 2008; Jiang 2008; Ashbaugh-Skaife et al. 2006).

In our second model, we test our primary hypothesis and examine the importance of SOX 404 material internal control deficiency disclosures conditioned upon the existence of prior SOX 302 disclosures. Thus, we add two indicator variables. The first (DEF404+302) is equal to one if the firm indicated a material SOX 404 internal control deficiency identified by the auditors that was preceded by a material SOX 302 internal control deficiency announced by management in the previous three quarters. The second indicator variable (DEF404-302) is equal to one if the firm indicated a material SOX 404 internal control deficiency but was not preceded by a material SOX 302 disclosure in the previous three quarters. Each of these two indicators variables are found to be significant in Model 2 with DEF404+302 ( $\mathrm{p}=.031$ ) displaying slightly more significance than DEF404-302 ( $\mathrm{p}=.066$ ). This is consistent with the SOX 404 disclosures attested by the auditors being an important factor in the determination of firm credit ratings, and being slightly more important when there was no prior warning of internal control difficulty from management via SOX 302 disclosures. These findings provide some preliminary support for H2. 
Table 2: Correlation Matrix

\begin{tabular}{|c|c|c|c|c|c|c|c|c|c|c|c|c|c|c|c|c|c|}
\hline Variables & 1 & 2 & 3 & 4 & 5 & 6 & 7 & 8 & 9 & 10 & 11 & 12 & 13 & 14 & 15 & 16 & 17 \\
\hline RATING & & -0.187 & 0.948 & 0.574 & 0.384 & 0.306 & -0.430 & -0.483 & 0.130 & 0.566 & -0.296 & 0.005 & 0.055 & -0.392 & 0.077 & -0.134 & -0.434 \\
\hline DEF404 & -0.194 & & -0.170 & -0.107 & -0.144 & -0.123 & 0.167 & 0.075 & -0.019 & -0.163 & 0.055 & -0.020 & -0.042 & 0.012 & -0.021 & 0.289 & 0.184 \\
\hline SIZE & 0.570 & -0.109 & 0.574 & & 0.057 & 0.081 & -0.166 & -0.289 & 0.094 & 0.245 & -0.169 & 0.034 & 0.009 & -0.233 & 0.037 & -0.074 & -0.266 \\
\hline ROA & 0.381 & -0.159 & 0.335 & 0.051 & & 0.684 & -0.417 & -0.192 & 0.044 & 0.626 & -0.073 & -0.028 & -0.149 & -0.084 & 0.055 & -0.109 & -0.149 \\
\hline $\mathrm{CFO}$ & 0.327 & -0.130 & 0.296 & 0.089 & 0.671 & & -0.309 & -0.204 & 0.076 & 0.582 & -0.108 & 0.242 & -0.081 & -0.071 & -0.011 & -0.085 & -0.158 \\
\hline LOSS & -0.430 & 0.167 & -0.370 & -0.166 & -0.441 & -0.327 & & 0.303 & 0.066 & -0.403 & 0.096 & 0.014 & -0.073 & 0.298 & -0.059 & 0.105 & 0.232 \\
\hline LEV & -0.482 & 0.063 & -0.468 & -0.273 & -0.249 & -0.262 & 0.259 & & -0.191 & -0.639 & 0.317 & 0.178 & -0.248 & 0.209 & -0.079 & 0.043 & 0.199 \\
\hline $\mathrm{RD}$ & 0.186 & -0.008 & 0.179 & 0.127 & 0.115 & 0.073 & 0.014 & -0.27 & & 0.259 & -0.112 & -0.235 & -0.095 & 0.000 & 0.061 & -0.014 & -0.168 \\
\hline TIMES & 0.594 & -0.173 & 0.562 & 0.253 & 0.660 & 0.616 & -0.438 & -0.706 & 0.267 & & -0.257 & -0.061 & 0.021 & -0.168 & 0.113 & -0.11 & -0.266 \\
\hline SUBORD & -0.316 & 0.055 & -0.318 & -0.179 & -0.065 & -0.121 & 0.096 & 0.299 & -0.100 & -0.278 & & -0.049 & -0.041 & 0.103 & 0.028 & 0.049 & 0.182 \\
\hline CAPINT & 0.035 & -0.023 & 0.043 & 0.055 & -0.041 & 0.211 & 0.002 & 0.182 & -0.278 & -0.064 & -0.062 & & -0.045 & 0.015 & -0.302 & -0.020 & 0.079 \\
\hline $\mathrm{BM}$ & -0.107 & 0.007 & -0.079 & -0.004 & -0.413 & -0.322 & 0.065 & -0.045 & -0.210 & -0.184 & 0.020 & 0.000 & & 0.031 & 0.054 & -0.004 & -0.001 \\
\hline STD_RET & -0.433 & 0.036 & -0.426 & -0.297 & -0.061 & -0.059 & 0.237 & 0.160 & -0.007 & -0.155 & 0.128 & -0.018 & 0.140 & & -0.045 & -0.014 & 0.266 \\
\hline MERGER & 0.075 & -0.021 & 0.084 & 0.038 & 0.087 & 0.015 & -0.059 & -0.073 & 0.114 & 0.133 & 0.028 & -0.301 & 0.022 & -0.038 & & -0.043 & -0.101 \\
\hline RESTATE & -0.139 & 0.289 & -0.129 & -0.078 & -0.118 & -0.092 & 0.105 & 0.041 & -0.027 & -0.127 & 0.049 & -0.023 & 0.022 & 0.003 & -0.043 & & 0.088 \\
\hline
\end{tabular}

All variables are defined in Table 1. Numbers above (below) the diagonal are from Pearson (Spearman) correlation.

Panel B: correlation of change of the variables

\begin{tabular}{|c|c|c|c|c|c|c|c|c|c|c|c|c|c|c|c|}
\hline Variables & 1 & 2 & 3 & 4 & 5 & 6 & 7 & 8 & 9 & 10 & 11 & 12 & 13 & 14 & 15 \\
\hline$\Delta$ RATING $[\mathrm{m}-1, \mathrm{~m}+1]$ & & -0.040 & 0.014 & 0.073 & 0.033 & -0.044 & -0.030 & -0.009 & 0.064 & -0.009 & 0.004 & -0.050 & -0.051 & -0.013 & -0.012 \\
\hline DEF404 & -0.041 & & -0.054 & -0.007 & -0.011 & 0.040 & -0.017 & -0.008 & -0.025 & -0.059 & 0.019 & -0.055 & -0.069 & -0.017 & 0.044 \\
\hline$\triangle \mathrm{SIZE}$ & 0.032 & -0.070 & & -0.151 & -0.192 & -0.059 & 0.086 & -0.144 & -0.113 & 0.062 & -0.521 & 0.088 & -0.118 & 0.158 & 0.001 \\
\hline$\triangle \mathrm{ROA}$ & 0.088 & -0.029 & -0.148 & & 0.421 & -0.231 & -0.096 & -0.007 & 0.544 & -0.009 & 0.009 & -0.106 & -0.030 & -0.053 & -0.007 \\
\hline$\Delta \mathrm{CFO}$ & 0.043 & -0.013 & -0.138 & 0.439 & & -0.129 & -0.117 & -0.010 & 0.306 & -0.023 & 0.124 & -0.088 & -0.035 & -0.085 & 0.006 \\
\hline$\Delta \mathrm{LOSS}$ & -0.045 & 0.041 & -0.082 & -0.251 & -0.119 & & 0.103 & 0.109 & -0.245 & -0.007 & 0.091 & 0.069 & 0.152 & -0.006 & 0.009 \\
\hline$\triangle \mathrm{LEV}$ & -0.057 & -0.020 & -0.024 & -0.206 & -0.178 & 0.176 & & 0.013 & -0.249 & 0.051 & 0.061 & 0.030 & 0.078 & 0.042 & -0.013 \\
\hline$\Delta \mathrm{RD}$ & -0.014 & 0.003 & -0.213 & 0.073 & 0.019 & 0.067 & -0.019 & & -0.027 & 0.008 & 0.119 & -0.033 & 0.015 & 0.037 & 0.001 \\
\hline$\Delta$ TIMES & 0.083 & -0.034 & 0.013 & 0.601 & 0.303 & -0.247 & -0.357 & 0.024 & & -0.055 & 0.011 & -0.078 & -0.062 & -0.015 & -0.008 \\
\hline$\triangle$ SUBORD & -0.009 & -0.059 & 0.055 & -0.011 & -0.015 & -0.007 & 0.065 & -0.016 & -0.051 & & -0.030 & 0.025 & 0.014 & 0.017 & -0.024 \\
\hline$\Delta$ CAPINT & 0.004 & 0.034 & -0.553 & 0.090 & 0.133 & 0.086 & 0.088 & 0.172 & -0.014 & -0.027 & & -0.001 & 0.124 & -0.096 & -0.008 \\
\hline$\Delta \mathrm{BM}$ & -0.036 & -0.064 & 0.057 & -0.213 & -0.136 & 0.035 & 0.028 & -0.000 & -0.116 & 0.011 & 0.011 & & 0.272 & -0.019 & -0.009 \\
\hline$\Delta$ STD_RET & -0.045 & -0.063 & -0.073 & -0.04 & -0.035 & 0.130 & 0.187 & 0.026 & -0.065 & 0.022 & 0.077 & 0.269 & & -0.039 & -0.024 \\
\hline$\triangle$ MERGER & -0.014 & -0.017 & 0.145 & -0.059 & -0.077 & -0.006 & 0.046 & 0.004 & 0.001 & 0.017 & -0.102 & 0.003 & -0.030 & & -0.010 \\
\hline$\triangle \mathrm{RESTATE}$ & -0.008 & 0.042 & 0.001 & -0.008 & -0.001 & 0.009 & -0.021 & 0.011 & -0.010 & -0.024 & -0.002 & -0.001 & -0.019 & -0.010 & \\
\hline
\end{tabular}

All variables are defined in Table 1. Numbers above (below) the diagonal are from Pearson (Spearman) correlation. 
Dependent variable $=$ RATING

\begin{tabular}{|c|c|c|c|c|}
\hline & \multicolumn{2}{|c|}{ Model 1} & \multicolumn{2}{|c|}{ Model 2} \\
\hline Variables & Estimates & p-values & Estimates & p-values \\
\hline (DEF404 =1) & -0.583 & 0.006 & & \\
\hline$($ DEF404 + 302) & & & -0.665 & 0.066 \\
\hline (DEF404 - 302) & & & -0.544 & 0.031 \\
\hline RATINGt-1 & 5.300 & $<.0001$ & 5.300 & $<.0001$ \\
\hline SIZE & 0.374 & $<.0001$ & 0.375 & $<.0001$ \\
\hline ROA & 7.801 & $<.0001$ & 7.800 & $<.0001$ \\
\hline $\mathrm{CFO}$ & 0.806 & 0.517 & 0.794 & 0.522 \\
\hline LOSS & -1.802 & $<.0001$ & -1.804 & $<.0001$ \\
\hline LEV & -0.683 & 0.125 & -0.685 & 0.124 \\
\hline $\mathrm{RD}$ & 3.939 & 0.073 & 3.939 & 0.073 \\
\hline TIMES & 0.531 & $<.0001$ & 0.531 & $<.0001$ \\
\hline SUBORD & -0.030 & 0.824 & -0.031 & 0.819 \\
\hline CAPINT & -0.283 & 0.100 & -0.282 & 0.101 \\
\hline $\mathrm{BM}$ & 0.178 & 0.049 & 0.178 & 0.049 \\
\hline STD_RET & -0.381 & $<.0001$ & -0.381 & $<.0001$ \\
\hline MERGER & -0.216 & 0.024 & -0.217 & 0.023 \\
\hline RESTATE & -0.281 & 0.106 & -0.275 & 0.117 \\
\hline Pseudo-R2 & & 0.755 & & 0.755 \\
\hline Likelihood Ratio & & 11291.8 & & 11291.9 \\
\hline $\mathrm{N}$ & & 4,825 & & 4,825 \\
\hline
\end{tabular}

We attempt to gain more insight into this issue by changing the structure of our analyses to examine the importance of SOX 302 disclosures conditioned upon the existence of previous SOX 404 disclosures. We accomplish this by running a base SOX 302 model, and then including two additional indicator variables. The first (DEF302+404) is equal to one if the firm's management indicated a material SOX 302 internal control deficiency that was preceded by a material SOX 404 internal control deficiency identified by the auditors in the prior year. The second indicator variable (DEF302-404) is equal to one if the firm indicated a material SOX 302 internal control deficiency but was not preceded by a material SOX 404 disclosure in the previous year. The results of these analyses are shown in Table 4.

Dependent variable $=$ RATINGQ

Table 4: Credit Rating and SOX 302 Disclosure

\begin{tabular}{|c|c|c|c|c|}
\hline & \multicolumn{2}{|c|}{ Model 3} & \multicolumn{2}{|c|}{ Model 4} \\
\hline Variables & Estimates & p-values & Estimates & p-values \\
\hline DEF302 & -0.884 & 0.008 & & \\
\hline$($ DEF302 + 404) & & & -1.030 & 0.002 \\
\hline (DEF302 - 404) & & & -0.500 & 0.443 \\
\hline RATINGQ_1 & 8.334 & $<.0001$ & 8.340 & $<.0001$ \\
\hline SIZEQ & 0.225 & 0.012 & 0.226 & 0.011 \\
\hline ROAQ & 16.493 & 0.009 & 16.782 & 0.007 \\
\hline CFOQ & -1.288 & 0.491 & -1.398 & 0.456 \\
\hline LOSSQ & -1.224 & $<.0001$ & -1.233 & $<.0001$ \\
\hline LEVQ & 0.246 & 0.770 & 0.235 & 0.778 \\
\hline RDQ & 9.699 & 0.455 & 9.784 & 0.450 \\
\hline TIMESQ & 0.663 & $<.0001$ & 0.663 & $<.0001$ \\
\hline SUBORDQ & -0.172 & 0.601 & -0.175 & 0.595 \\
\hline CAPINTQ & 0.047 & 0.896 & 0.058 & 0.871 \\
\hline BMQ & -0.578 & 0.042 & -0.583 & 0.038 \\
\hline STD_RETQ & -0.213 & 0.050 & -0.212 & 0.051 \\
\hline MERGERQ & 0.135 & 0.444 & 0.136 & 0.440 \\
\hline RESTATEQ & 0.337 & 0.517 & 0.319 & 0.533 \\
\hline Likelihood Ratio & 15924.26 & $<.0001$ & 15918.903 & $<.0001$ \\
\hline Pseudo-R2 & 0.901 & 0.901 & & \\
\hline $\mathrm{N}$ & & 5,795 & & 5,795 \\
\hline
\end{tabular}


Model 3 demonstrates the results of including a single indicator variable (DEF302) which specifies the existence of a material weakness in internal controls as announced by a firm's management in a SOX 302 disclosure. The single DEF302 variable $(\mathrm{p}=.008)$ is found to be negatively associated with a firm's credit rating. Further examination of this result in Model 4 indicates that SOX 302 material weakness disclosure preceded by the auditor attested SOX 404 internal control weaknesses appear to be driving the overall results (DEF302+404 p-value $=.002$ ) while SOX 302 announced internal control weaknesses not preceded by a SOX 404 internal control weakness are not found to be a significant factor in the determination of a firm's credit ratings (DEF302-404 $\mathrm{p}=.443$ ). These results are consistent with the conjecture that the most important component for determination of credit ratings are the auditor attested SOX 404 announcement of problems with internal control. These findings provide further support for our hypothesis. The next section investigates our question further by examining the effects of SOX 302 and 404 disclosures on credit rating changes.

\section{CHANGES IN CREDIT RATINGS}

\section{SOX 404 Announcements}

We now examine the effects of announced internal control deficiencies in the context of credit rating changes. Similar to our levels analyses described previously, we begin by examining the effect of a SOX 404 announcement. The results are shown in Table 5 under Model 5 and illustrate that a SOX 404 internal control deficiency attested to by a firm's auditors is negatively associated with a firm's changes on bond ratings ( $\mathrm{p}=.011)$. This is consistent with the interpretation that firm's announcing a SOX 404 internal control deficiency are more likely to experience a lowering of their credit rating.

Table 5: Event Study: Impact of SOX 404 Disclosure on Credit Rating Dependent variable $=\Delta$ RATING $[\mathbf{m}-1, \mathbf{m + 1}]$

Model 5

\begin{tabular}{|c|c|c|c|c|}
\hline Variables & Estimates & p-values & Estimates & p-values \\
\hline (DEF404 =1) & -0.976 & 0.011 & & \\
\hline$($ DEF404 + 302) & & & -0.927 & 0.042 \\
\hline (DEF404 - 302) & & & -1.088 & 0.093 \\
\hline$\triangle \mathrm{SIZE}$ & 0.980 & 0.035 & 0.986 & 0.033 \\
\hline$\triangle \mathrm{ROA}$ & 5.775 & $<.0001$ & 5.770 & $<.0001$ \\
\hline$\triangle \mathrm{CFO}$ & 0.256 & 0.914 & 0.248 & 0.917 \\
\hline$\Delta \mathrm{LOSS}$ & -0.227 & 0.431 & -0.227 & 0.431 \\
\hline$\Delta \mathrm{LEV}$ & -0.678 & 0.021 & -0.678 & 0.021 \\
\hline$\Delta \mathrm{RD}$ & -4.433 & 0.724 & -4.537 & 0.719 \\
\hline$\Delta \mathrm{TIMES}$ & 0.317 & 0.138 & 0.318 & 0.137 \\
\hline$\triangle$ SUBORD & -0.277 & 0.437 & -0.274 & 0.443 \\
\hline$\triangle$ CAPINT & 2.071 & 0.057 & 2.081 & 0.056 \\
\hline$\Delta \mathrm{BM}$ & -0.607 & 0.078 & -0.608 & 0.077 \\
\hline$\Delta$ STD_RET & -0.638 & 0.024 & -0.638 & 0.024 \\
\hline$\triangle$ MERGER & -0.214 & 0.270 & -0.214 & 0.272 \\
\hline$\triangle$ RESTATE & -0.118 & 0.702 & -0.115 & 0.711 \\
\hline Likelihood Ratio & 57.71 & $<.0001$ & 57.77 & $<.0001$ \\
\hline Pseudo-R2 & & 0.045 & & 0.045 \\
\hline $\mathrm{N}$ & & 4,570 & & 4,570 \\
\hline
\end{tabular}

Note: All variables are defined in Table 1. Coefficients on year and industry dummies are not included for brevity. P-values are two-tailed and are estimated based on t-values clustered by firm.

To examine the effect of SOX 404 deficiencies conditioned upon a prior SOX 302 internal control deficiency announcement by management in the prior three quarters, we include the two indicator variables described earlier in the levels analyses (DEF404+302 and DEF404-302). The results are shown in Model 6 of Table 5 and demonstrate the announcement of a SOX 404 internal control weakness by a firm's auditors appears to be associated with a decrease in credit rating regardless of whether the firm's management had made a prior SOX 302 
announcement (DEF404+302 p=.042; DEF404-302 p=.093). This is consistent with the interpretation that the SOX 404 announcement of a weakness by the auditor is the more important revelation to credit rating analysts.

\section{SOX 302 Announcements}

To help ensure our interpretation of the SOX 404 announcements are valid, we rerun our changes analyses by first inserting an indicator variable signifying a SOX 302 announcement, and then run an additional model with two other dummy variables that condition the SOX 302 announcement on a prior SOX 404 announcement. The results of these analyses are shown in Table 6 where Model 7 demonstrates that a SOX 302 announcement is not a significant factor in the credit rating change model (DEF302 p=.742). Additional evidence is found in the results of Model 8 which illustrates that regardless of whether firm auditors made a SOX 404 attestation of an internal control weakness in the previous period (DEF302+404 p=.323) or not (DEF302-404 p=.239), there does not appear to be any significant association of management's SOX 302 announcements with changes in a firm's credit ratings. These results provide further corroboration of our previous results that are consistent with the auditor's attestation of an internal control deficiency via a SOX 404 announcement being more relevant information than SOX 302 announcements with respect to bond rating changes.

Table 6: Event Study: Impact of SOX 302 Disclosure on Credit Rating Dependent variables $=\triangle$ RATINGQ $[\mathbf{m}-1, \mathbf{m}+1]$

Model 7

Model 8

\begin{tabular}{|c|c|c|c|c|}
\hline Variables & Estimates & p-values & Estimates & p-values \\
\hline DEF302 & -0.143 & 0.742 & & \\
\hline$($ DEF302 + 404) & & & 0.229 & 0.323 \\
\hline (DEF302 - 404) & & & -1.056 & 0.239 \\
\hline$\triangle$ SIZEQ & 1.444 & 0.032 & 1.450 & 0.032 \\
\hline$\triangle \mathrm{ROAQ}$ & 17.322 & 0.028 & 16.587 & 0.038 \\
\hline$\triangle \mathrm{CFOQ}$ & 1.042 & 0.728 & 1.208 & 0.688 \\
\hline$\Delta \mathrm{LOSSQ}$ & -0.218 & 0.649 & -0.230 & 0.625 \\
\hline$\triangle \mathrm{LEVQ}$ & 1.174 & 0.546 & 1.158 & 0.544 \\
\hline$\triangle \mathrm{RDQ}$ & 98.538 & 0.001 & 99.038 & 0.001 \\
\hline$\Delta$ TIMESQ & 0.225 & 0.510 & 0.233 & 0.493 \\
\hline$\triangle$ SUBORDQ & 0.564 & 0.571 & 0.579 & 0.563 \\
\hline$\triangle \mathrm{CAPINTQ}$ & 1.970 & 0.301 & 1.978 & 0.288 \\
\hline$\triangle \mathrm{BMQ}$ & -0.465 & 0.39 & -0.442 & 0.411 \\
\hline$\triangle \mathrm{STD} \_\mathrm{RETQ}$ & -0.259 & 0.188 & -0.247 & 0.216 \\
\hline$\triangle \mathrm{MERGERQ}$ & -0.352 & 0.036 & -0.355 & 0.036 \\
\hline$\triangle$ RESTATEQ & 0.022 & 0.853 & 0.083 & 0.571 \\
\hline Likelihood Ratio & 27.310 & 0.018 & 28.281 & 0.020 \\
\hline Pseudo-R2 & & 0.049 & & 0.051 \\
\hline $\mathrm{N}$ & & 5,322 & & 5,322 \\
\hline
\end{tabular}

\section{INTERNAL CONTROL DEFICIENCIES AND COST OF DEBT}

To look at the issue from a somewhat different perspective and provide some sensitivity analyses with respect to our investigation of credit ratings, we extend our previous analyses to explore the effects of the existence of identified internal control deficiencies on a firm's Cost of Debt. We estimate the Cost of Debt following Francis et al. (2005), and then investigate the association of SOX 404 and SOX 302 announcements in a manner similar to our levels analyses described above for credit ratings. First, we analyze the effects of SOX 404 conditioned upon the existence of a SOX 302 announcement in a prior period, and then we modify the model to investigate the effects of SOX 302 conditioned on a previous SOX 404 announcement.

The results of our SOX 404 investigation with respect to a firm's Cost of Debt are provided in Table 7 in which Model 9 demonstrates that the existence of an auditor attested internal control deficiency is highly associated with a firm's Cost of Debt (DEF404 p=.001). These results are further supported in Model 10 when we condition the 
SOX 404 announcement upon a previous SOX 302 announcement in the prior three quarters. Regardless of whether the firm's management described an internal control weakness in a SOX 302 announcement (DEF404+302 p=.021) or did not announce an internal control weakness in the prior three quarters (DEF404-302 p=.002), the existence of an auditor attested SOX 404 deficiency remains positively associated with a firm's Cost of Debt.

\section{Dependent variables $=$ COD}

\begin{tabular}{|c|c|c|c|c|}
\hline & \multicolumn{2}{|c|}{ Model 9} & \multicolumn{2}{|c|}{ Model 10} \\
\hline Variables & Estimates & p-values & Estimates & p-values \\
\hline Intercept & 0.109 & $<.0001$ & 0.109 & $<.0001$ \\
\hline (DEF404 =1) & 0.006 & 0.001 & & \\
\hline$($ DEF404 + 302) & & & 0.005 & 0.021 \\
\hline (DEF404 - 302) & & & 0.006 & 0.002 \\
\hline RATING & -0.005 & $<.0001$ & -0.005 & $<.0001$ \\
\hline SIZE & -0.001 & 0.143 & -0.001 & 0.142 \\
\hline ROA & 0.093 & $<.0001$ & 0.093 & $<.0001$ \\
\hline $\mathrm{CFO}$ & -0.018 & 0.083 & -0.018 & 0.083 \\
\hline LOSS & 0.003 & 0.006 & 0.003 & 0.006 \\
\hline LEV & -0.040 & $<.0001$ & -0.040 & $<.0001$ \\
\hline $\mathrm{RD}$ & -0.038 & 0.171 & -0.038 & 0.171 \\
\hline TIMES & -0.013 & $<.0001$ & -0.013 & $<.0001$ \\
\hline SUBORD & 0.003 & 0.003 & 0.003 & 0.003 \\
\hline CAPINT & 0.009 & $<.0001$ & 0.009 & $<.0001$ \\
\hline $\mathrm{BM}$ & -0.004 & 0.006 & -0.004 & 0.006 \\
\hline STD_RET & 0.003 & $<.0001$ & 0.003 & $<.0001$ \\
\hline MERGER & -0.001 & 0.489 & -0.001 & 0.487 \\
\hline RESTATE & -0.001 & 0.437 & -0.001 & 0.453 \\
\hline F-values & 24.00 & $<.0001$ & 23.68 & $<.0001$ \\
\hline Adj. R2 & & 0.328 & & 0.328 \\
\hline $\mathrm{N}$ & & 3,575 & & 3,575 \\
\hline
\end{tabular}

Note: All variables are defined in Table 1. Coefficients on year and industry dummies are not included for brevity. P-values are two-tailed and are estimated based on t-values clustered by firm.

We next examine the importance of SOX 302 announcements on a firm's Cost of Debt, conditioned on the existence of a prior SOX 404 announcement. The results provided in Model 11 of Table 8 demonstrate that a SOX 302 announcement alone appears to be associated with a firm's Cost of Debt (DEF302 p=.072). However, when the single DEF302 variable is removed, and replaced in Model 12 with our two DEF302 indicator variables conditioned on DEF404 prior status, we see the SOX 302 announcement is only significant when there was a previous SOX 404 announcement in the prior period (DEF302+404 p=.066). The SOX 302 announcement is not found to be significant when it was not preceded by a SOX 404 announcement in the prior period (DEF302-404 p=.360). These results are consistent with the interpretation that the auditor attested SOX 404 announcement of an internal control weakness appears to be a significant factor in explaining a firm's Cost of Debt while the SOX 302 management announcement alone does not carry nearly as much influence. These results provide further corroboration of H1 indicating that information related to internal control deficiencies are a significant component in determining a firm's credit rating and Cost of Debt. Furthermore, the information provided by a SOX 404 announcement regarding the deficiencies appears to be the most influential component of these announcements. This is consistent with the interpretation that the external auditor's attestation required by SOX 404 is considered important by debt market participants. 
Table 8: Cost of Debt and SOX 302 Disclosure

Dependent variable $=$ CODQ

\begin{tabular}{|c|c|c|c|c|}
\hline & \multicolumn{2}{|c|}{ Model 11} & \multicolumn{2}{|c|}{ Model 12} \\
\hline Variables & Estimates & p-values & Estimates & p-values \\
\hline Intercept & 0.025 & $<.0001$ & 0.025 & $<.0001$ \\
\hline DEF302 & 0.001 & 0.072 & & \\
\hline$($ DEF302 + 404) & & & 0.001 & 0.066 \\
\hline (DEF302 - 404) & & & 0.001 & 0.360 \\
\hline RATINGQ & -0.002 & $<.0001$ & -0.002 & $<.0001$ \\
\hline SIZEQ & -0.0004 & 0.006 & -0.0004 & 0.006 \\
\hline ROAQ & -0.001 & 0.943 & -0.001 & 0.939 \\
\hline CFOQ & 0.004 & 0.166 & 0.004 & 0.160 \\
\hline LOSSQ & 0.001 & 0.002 & 0.001 & 0.001 \\
\hline LEVQ & -0.002 & 0.087 & -0.002 & 0.090 \\
\hline RDQ & -0.059 & 0.059 & -0.059 & 0.059 \\
\hline TIMESQ & -0.0001 & $<.0001$ & -0.0001 & $<.0001$ \\
\hline SUBORDQ & 0.001 & 0.148 & 0.001 & 0.147 \\
\hline CAPINTQ & -0.001 & 0.132 & -0.001 & 0.130 \\
\hline BMQ & -0.001 & 0.054 & -0.001 & 0.056 \\
\hline STD_RETQ & 0.013 & 0.237 & 0.013 & 0.238 \\
\hline MERGERQ & 0.0002 & 0.418 & 0.0002 & 0.422 \\
\hline RESTATEQ & 0.0003 & 0.405 & 0.0003 & 0.375 \\
\hline F-values & 33.76 & $<.0001$ & 33.32 & $<.0001$ \\
\hline Adj. R2 & & 0.307 & & 0.307 \\
\hline $\mathrm{N}$ & & 5,539 & & 5,539 \\
\hline
\end{tabular}

Note: All variables are defined in Table 1. The estimations are based on data from Quarters 1 to 3. Coefficients on year and industry dummies are not included for brevity. P-values are two-tailed and are estimated based on t-values clustered by firm.

\section{CONCLUSIONS}

Auditor attestation of firm internal control relating to external financial reporting systems is arguably an advancement in corporate disclosure that can help investors and creditors evaluate overall firm risk. We add to existing research by providing empirical evidence concerning the importance of SOX 404 internal control assessment disclosures for credit ratings. Our results are consistent with these disclosures providing useful information to credit analysts, and this information being a significant factor in determining a firm's credit ratings. We also provide additional corroboration for our conclusions by finding these SOX 404 announcements to be significantly associated with changes in a firm's credit ratings, as well as with a firm's cost of debt. Finally, we find that the internal control system information provided by the firm's management in SOX 302 do not by themselves appear to provide substantive information to the credit markets. Only when SOX 302 announcements are provided in conjunction with SOX 404 auditor attested internal control deficiencies do they become important in the determination of credit ratings and the firm's cost of debt. These results should be of significance to those interested in factors that influence a firm's credit ratings, changes in credit ratings, and cost of debt. These findings should also be of interest to those involved in the public policy debate concerning the continuation of SOX 404 required disclosures related to internal control system deficiencies, and more generally, those interested in corporate disclosures.

\section{ACKNOWLEDGEMENT}

The authors greatly appreciate valuable comments and suggestions from Bill Kinney, Tom Omer, participants in the $4^{\text {th }}$ Lonestar Accounting Research Conference and participants in the 2009 AAA Conference.

\section{AUTHOR INFORMATION}

Aaron D. Crabtree is the KPMG Faculty Fellow and Associate Professor at the University of Nebraska-Lincoln. His research interests and recent publications focus on firm cost of debt. Specifically, Dr. Crabtree has examined taxes, book-tax differences, and audit-related characteristics on the firm's bond ratings and yields. E-mail: acrabtree2@unl.edu 
John J. Maher is the John F. Carroll, Jr. Professor in the Department of Accounting \& Information Systems, Pamplin College of Business, Virginia Tech. Maher's research has examined the proper measurement, valuation, and reporting for ill-defined corporate liabilities such as defined benefit pensions, medical benefits for retirees, and environmental obligations. More recently, Maher has investigated the effects of book-tax differences on corporate credit markets, the effects of auditor industry expertise on earnings quality, and the effects of non-audit service fees on perceived audit quality. Maher's research interests involve decision modeling directly related to accounting with particular emphasis on debt markets. E-mail: jmaher@vt.edu (Corresponding author)

\section{REFERENCES}

1. American Bankers Association (ABA). 2005. Comments submitted to the SEC roundtable on implementation of internal control reporting provisions. Washington, D.C.: SEC.

2. Anderson R.C., S.A. Mansi, D. M. Reeb. 2004. Board characteristics, accounting report integrity, and the cost of debt. Journal of Accounting and Economics 37 (3) 315-342.

3. Ashbaugh-Skaife H., D. Collins, R. LaFond. 2006. The effects of corporate governance on firms' credit ratings. Journal of Accounting and Economics 42 (2) 203-243.

4. Ashbaugh-Skaife H., D. Collins, W. Kinney. 2007. The discovery and reporting of internal control deficiencies prior to SOX-mandated audits. Journal of Accounting and Economics 44: 166-192.

5. Ashbaugh-Skaife H., D. Collins, W. Kinney, R. LaFond. 2008. The effect of SOX internal control deficiencies and their remediation on accrual quality. The Accounting Review 83 (1): 217-250.

6. Ashbaugh-Skaife H., D. Collins, W. Kinney, R. LaFond. 2009. The effect of SOX internal control deficiencies on firm risk and cost of equity capital. Journal of Accounting Research 47 (1): 1-43.

7. Beatty, A., J. Weber, J.J. Yu. 2008, Conservatism and debt. Journal of Accounting and Economics 45 (2008): 154-174.

8. Beneish, M.D., M.B. Billings, L.D. Hodder. 2008. Internal control weaknesses and information uncertainty. The Accounting Review 83 (3): 665-703.

9. Bhanot, K. and A.S. Mello. 2006. Should corporate debt include a rating trigger? Journal of Financial Economics 79: 69-98.

10. Chan, K.C., B.R. Farrell, P. Lee. 2008. Earnings management of firms reporting material internal control deficiencies under section 404 of the Sarbanes-Oxley act. Auditing: A Journal of Practice and Theory. Forthcoming.

11. Covitz, D.M. and P. Harrison. 2003. Testing conflicts of interest at bond rating agencies with market anticipation: Evidence that reputation incentives dominate. Working paper, Federal Reserve Board.

12. Dhaliwal, D. S., C. E. Hogan, R. Trezevant, and M. Wilkins. 2009. Internal control disclosures and the cost of debt. Working paper, University of Arizona.

13. Doyle, J.T.,W. Ge, S. McVay. 2007. Accruals quality and internal control or financial reporting. The Accounting Review 82 (5):1141-1170.

14. Elbannan, M. A., 2009, Quality of internal control over financial reporting, corporate governance and credit ratings. International Journal of Disclosure and Governance 6 (2):127-149.

15. Fitch Ratings. 2005. Sarbanes-Oxley Section 404: Fitch's approach to evaluating management and auditor assessments of internal controls. New York, NY. Fitch.

16. Francis, J., R. LaFond, P.Olsson and K. Schipper. 2005 The market pricing of accruals quality, Journal of Accounting and Economics, 39 (2,Jun): 295-327.

17. Gompers, P., J. Ishii and A. Metrick, 2003, "Corporate governance and equity prices", The Quarterly Journal of Economics 118: 107-155.

18. Hand, J. R., R. W. Holthausen, R. W. Leftwich. 1992. The effect of bond rating agency announcements on bond and stock prices. Journal of Finance, 47: 733-752.

19. Hogan, C. E. and M. S. Wilkins. "Evidence on the audit risk model: Do auditors increase audit fees in the presence of internal control deficiencies?," Contemporary Accounting Research, 2008, v25(1,Spring), 219242.

20. Holthausen, R. W., and Leftwich, R. W. 1986. The effect of bond rating changes on common stock prices. Journal of Financial Economics, 17: 57-90.

21. Huang, J. and M. Huang. 2003. How much of the corporate-treasury yield spread is due to credit risk? Working paper, Pennsylvania State University. 
22. IDD Inc. 2006 Investment Dealer's Digest. January 9.

23. Jiang, J. 2008. Beating earnings benchmarks and cost of debt. The Accounting Review 83(2): $377-416$.

24. Kaplan, R., Urwitz, G., 1979. Statistical models of bond ratings: a methodological inquiry. Journal of Business 52: 231-261.

25. Kinney, W., L., McDaniel. 1989. Characteristics of firms correcting previously reported quarterly earnings. Journal of Accounting and Economics 11: 71-93.

26. Kliger, D., O. Sarig. 2000. The information value of bonds. The Journal of Finance, 55 (6): $2879-2902$.

27. Krishnan, J. 2005. Audit committee quality and internal control: an empirical analysis. The Accounting Review 80: 649-675.

28. Lambert, R., C. Leuz, R. Verrecchia. 2007. Accounting information, disclosure, and cost of capital. Journal of Accounting Research 45(2): 385-420.

29. Lee, Y. 2008. The effect of employee stock options on credit rating. The Accounting Review 83 (5): $1273-$ 1314.

30. Li, C., K. H. Rupley and K. M. Johnstone. 2008. Internal governance, external governance, and internal control material weakness remediation. Working paper, University of Pittsburgh .

31. Mansi, S.A., W.F. Maxwell, D.P. Miller. 2004. Does auditor quality and tenure matter to investors? Evidence from the bond market. Journal of Accounting Research 42 (4)755-793.

32. Microsoft, Inc. 2005. Comment submitted to the SEC roundtable on implementation of internal control reporting provisions. Washington, D.C.: SEC.

33. Moody's Investor Service (Moody’s). 2007. Special comment: Third year of section 404 reporting on internal control. New York, NY: Moody's Investor Service.

34. Moody's Investor Service (Moody’s). 2004. Special comment: Section 404 reports on internal control. New York, NY: Moody's Investor Service.

35. Ogneva, M. K.R. Subramanyam, K. Raghunandan, 2007. Internal control weakness and cost of equity: Evidence from SOX section 404 disclosures. The Accounting Review 82 (5):1255-1297.

36. Penman, S. (2007). Financial statement analysis and security valuation, Third Edition. New York: McGraw-Hill.

37. SEC, 2002. Final Rule: Certification of disclosure in companies' quarterly and annual reports. Security and Exchange Commission. Release No. 33-8124

38. S\&P Ratings Group. 2008. S\&P Corporate rating criteria. New York, NY: Standard \& Poor's.

39. U.S. House of Representatives. 2005. The impact of the Sarbannes-Oxley Act. Hearing before the Committee on Financial Services. April 21. Washington, D.C.: Government Printing Office.

40. U.S. Senate. 2004. Examining the impact of the Sarbannes-Oxley act and developments concerning international commerce. Hearings before the Committee on Banking, Housing, and Urban Affairs. S.108850. September 9. Washington, D.C.: Government Printing Office.

41. Wall Street Journal. 2007. Solving 'Official' problem. Wall Street Journal, September 27: C16.

42. Ziebart, D., Reiter, S., 1992. Bond ratings, bond yields and financial information. Contemporary Accounting Research 9: 252-282. 